through all the stages being but thirtyfive days. Whether one or inore broods are raised before the one that lives through the winter, I am unable to say, though it may reasonably be presumed that such is the case. The last brood remains in the larval stage throughout the winter, usually emerging as adults in the latter half of April.

The parasites affecting this insect are all of small size, and one cell in four on an average is affected. Those bred by the writer are as follows:

Chrysis parvula Fabr. Two specimens.

Encyrtus sp? These tiny parasites had attacked the larva of the bee, consuming the whole interior and leaving the skin intact. Within this covering the pupae of the parasite, from Io to i 5 in number, were closely packed. The adults issued in the last week of February and the first week in May.

Aetroxys analis Ashmead n. sp. I I specimens.

q. Length $5.5 \mathrm{~mm}$. Bronzy green, scaly punctate, the tip of the abdomen yellowish; scape and legs, except coxae, ferruginous, the knees, tips of tibiae and tarsi more yellowish. Wings hyaline, the veins pale brown, the marginal vein about one and onehalf times as long as the stigmal, the post marginal vein as long as or slightly longer than the marginal. Abdomen very long acuminate, fully twice as long as the head and thorax united.

§. Length 2 to $2.5 \mathrm{~mm}$. Differs only in the shape of the abdomen which is elongate and only one-third longer than the head and thorax united, while the flagellum is filiform, pubescent, the first joint the longest, joints 3 to 5 subequal, about twice as long as thick.

Mr. Ashmead, in a note appended to this description, says: "The antennae in the $q$ are broken off at the pedicel, and I am therefore unable to tell to what subgenus of Aetroxys it belongs. The very long abdomen, which is tipped with yellow, readily distinguishes the species."

These eleven specimens were bred from six cells, five occupying one, and two each of the other three cells. On pupating they adhered together by the tip of the abdomen in one mass. All issued May 29.

\title{
THE NUMBER OF STAGES IN APATELODES TORREFACTA.
}

\section{BY HARRISON G. DYAR, NEW YORK CITY.}

I have already referred to the varying number of stages in this species (Psyche, vi, 146) as found by different authors; Miss Soule finding five and Dr. Packard six, while I presented evidence indicating eight stages. I returned to the subject last summer, as I succeeded in obtaining eggs by the assistance of
Mr. Jacob Doll from whom I purchased living pupae and. Miss Emily L. Morton who very kindly attended to the mating of the moths bred from them. The larvae exhibited five stages, but a consideration of the width of the head makes the whole matter clear. I gave the following series as probable, in my 
previous note: $.64, .8$, г.o, г.3, г.6, 2. $, 2.6,3.2 \mathrm{~mm}$. The present larvae exhibited .65,.8, 1.3, 2.2, 3.3, thus omitting every alternate stage after the second. In my larva formerly described, the last four measurements of the normal series were actually observed, and the larva must have had as many as seven stages, omitting normal iii, or perhaps eight, including iii. It is probable that in Dr. Packard's example but two stages were omitted, although we cannot say which, as he does not give us measurements of the head. Miss Soule's was doubtless the same as my last.

I will not describe the egg and larval stages in detail, as there is but little to add to the accounts already published. The arrangement of the hairs may be mentioned, as it is decidedly peculiar.

There is no primitive first stage. On hatching, the hairs are abundant, arising from low, flat granular wart areas, whose position is most difficult to determine positively, as they are obscured by the hairs, and when the latter are removed are difficult to distinguish, being merely concolorous granular areas. After repeated observation, I believe the accompanying cut represents
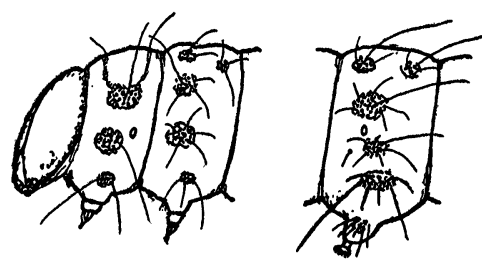

Apatelodes torrefacta.

their arrangement correctly. The hairs are represented as partly removed. On the abdomen i, ii, iii normal, iv very large and $v$ small, vi large, the base of the leg hairy. On the last two thoracic segments three warts above the stigmatal wart, the middle one moved back out of line with the others, stigmatal and subventral warts normal. I could not determine the exact period at which the secondary hairs appeared; probably in stage ii, though in my notes I state " secondary hairs not seen, if present can not distinguish them from those bending over from the warts." In the last stage, the secondary coating is well developed.

\section{DEIDAMIA INSCRJPTA.}

On June iI I found two larvae on a grapevine, and a few days later five more on Ampelopsis quinquefolia. The record is taken from the first two.

Length $\frac{3}{4}$ inch. Head round, green, with 4 very faint yellow face-lines. Body bright green, transversely striated with opaque yellow. 3rd and $4^{\text {th }}$ segments very slightly enlarged, too slightly to be noticed except by an entomologist. From the outer facelines to the caudal horn extended subdorsal lines of yellow, edged above with dark green. A stigmatal yellow edge ran from the first segment into the first oblique on each side. There were eight yellow obliques the eighth being under the caudal horn, and running backward from that. Anal shield edged with yellow. Caudal horn long, slender, straight, black, rough. Feet yellow, props green, venter plain green. 

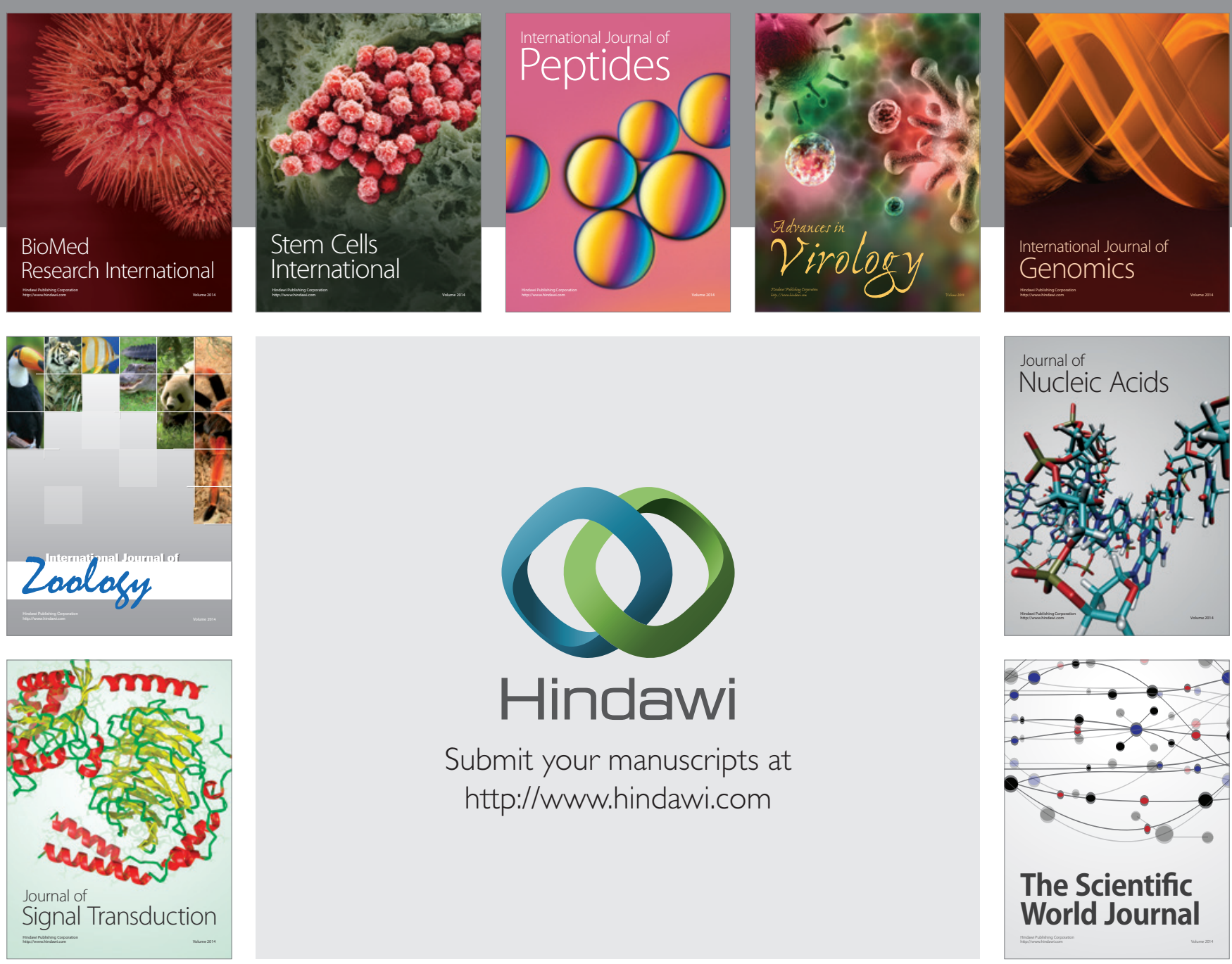

Submit your manuscripts at

http://www.hindawi.com
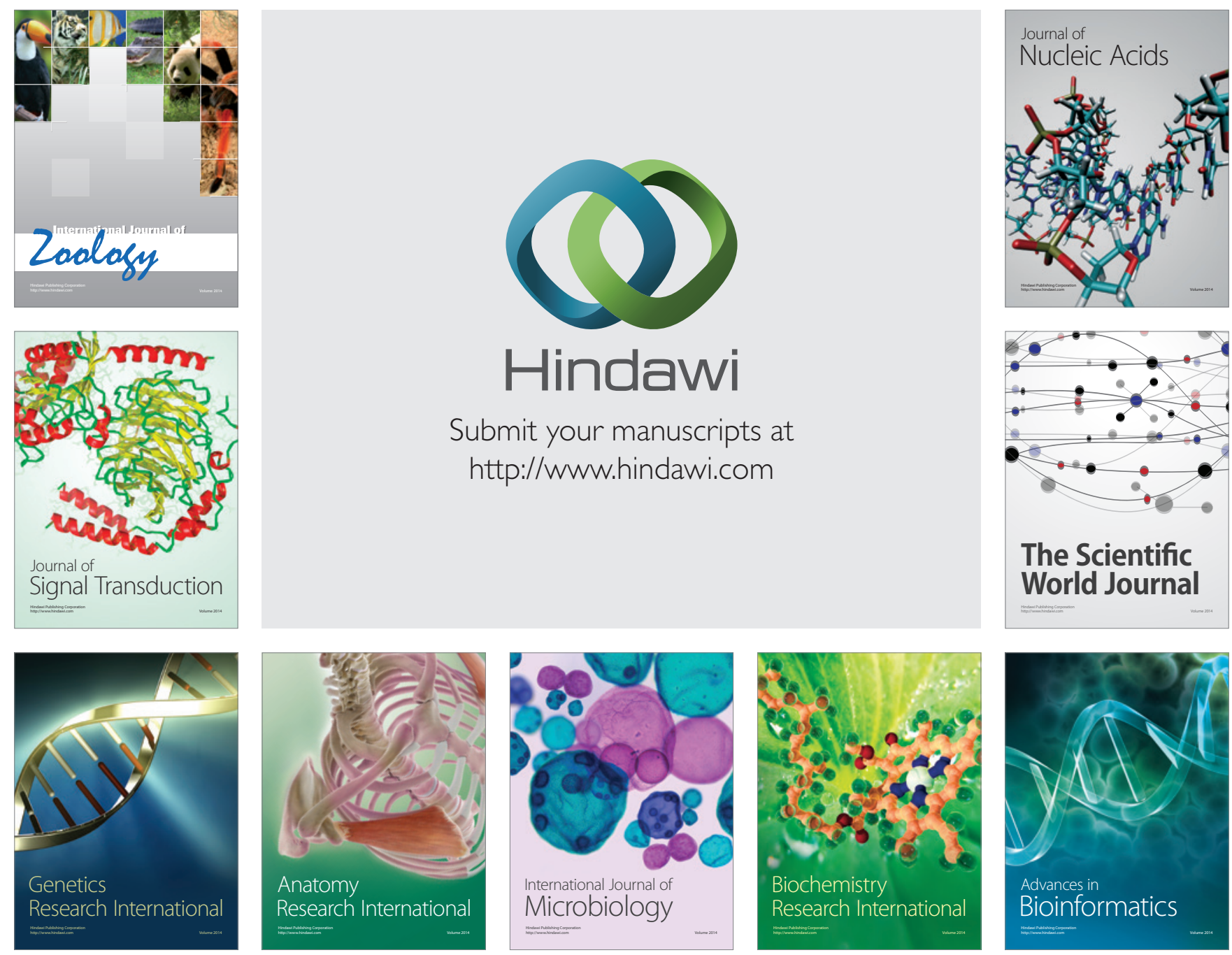

The Scientific World Journal
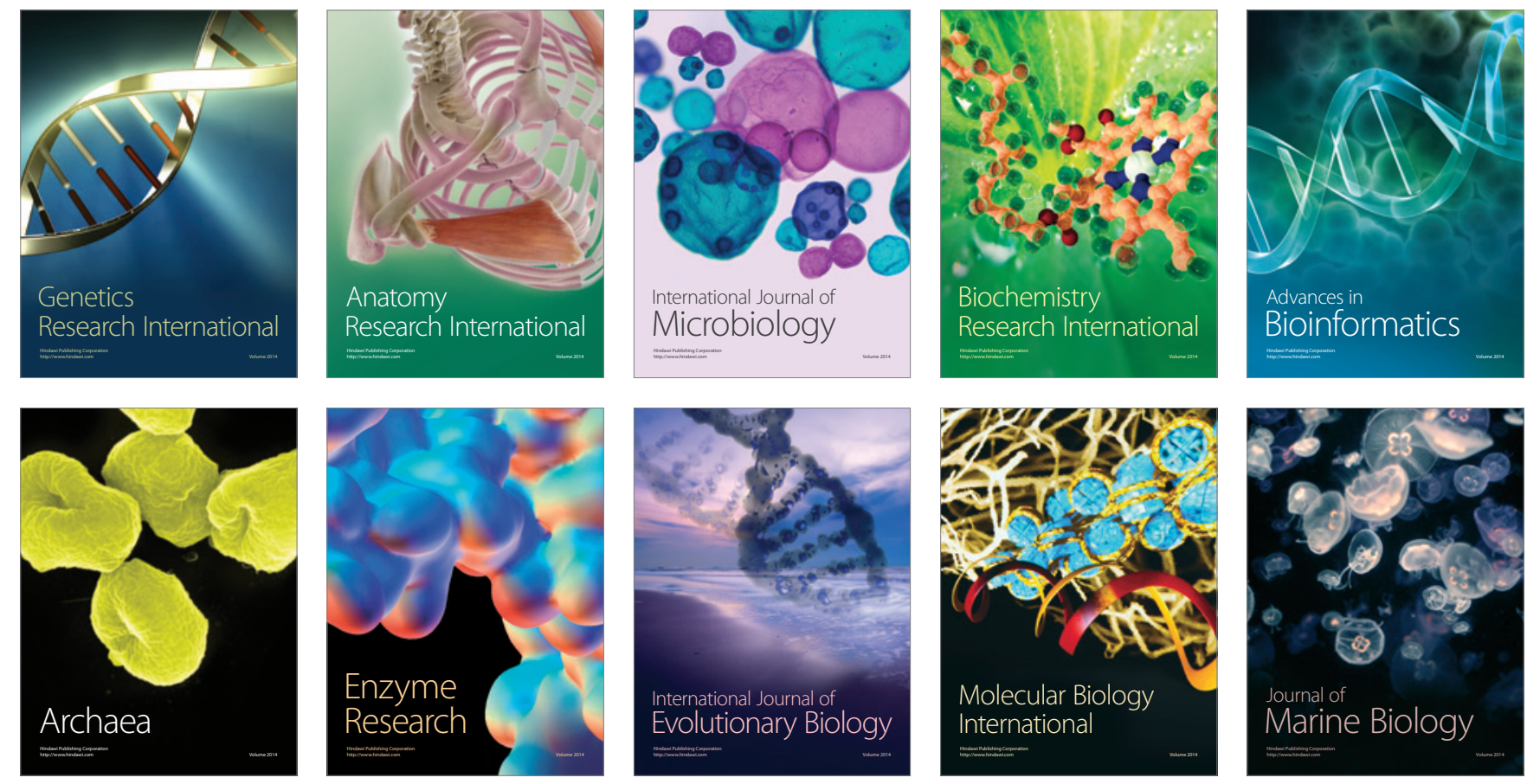